\title{
Sequestrated Carbon: Organic Carbon Pool in the Soils under Different Forest Covers and Land Uses in Garhwal Himalayan Region of India
}

\author{
M. K. Gupta ${ }^{1}$, S. D. Sharma ${ }^{2, *}$ \\ ${ }^{1}$ Forest Soils \& Land Reclamation Division, Forest Research Institute, Dehra Dun 248006, India \\ ${ }^{2}$ Forest Informatics Division, Forest Research Institute, Dehra Dun 248006, India
}

\begin{abstract}
Sequestration of atmospheric $\mathrm{CO}_{2}$ in the soil, as stable soil organic matter, provides a long lasting solution to decrease the $\mathrm{CO}_{2}$ in the atmosphere. The soil organic carbon pool was estimated in forests, tree plantations, horticulture and grasslands in the Garhwal area of Himalayan region which has wide variety of land uses and land cover. The forestry species included Shorea robusta, Cedrus deodara, Quercus leucotrichophora, Pinus roxburghii, Picea smithiana \& Abies pindrow, Pinus wallichiana and Miscellaneous species. Pyrus malus, Psidium guava, Mangifera indica, Citrus spp. and Lichee chinensis were the major fruit crops and the tree plantations comprised of Eucalyptus spp., Tectona grandis, Dalbergia sissoo and Pinus roxburghii. SOC pool was the maximum in the forest lands followed by grass lands, orchards and plantation areas. Differences in SOC pool under different land uses were statistically significant $(\mathrm{p}<0.05)$. The forests had 15.84 million tons $\left(78.49 \mathrm{t} \mathrm{ha}^{-1}\right)$ soil organic carbon pool in this region and P. smithiana \& A. pindrow forests had higher mitigation potential as they can store more than double SOC pool as compared to $S$. robusta. The soils under orchards contained 1.40 million tons SOC pool which is $13.05 \%$ of the total SOC pool of the orchards of Uttarakhand state. P. malus had the mitigation potential of 2.71 which indicates that it can have more than double SOC pool as compared to P. guava. SOC Pool in the grasslands was $75.76 \mathrm{t} \mathrm{ha}^{-1}$.
\end{abstract}

Keywords Soil Organic Carbon Pool, Natural Forests, Horticulture, Plantations, Grasslands

\section{Introduction}

Concentration of atmospheric $\mathrm{CO}_{2}$ can be lowered either by reducing emissions or by taking $\mathrm{CO}_{2}$ out from the atmosphere and stored in the terrestrial, oceanic or aquatic ecosystems. Several studies have established the fact that carbon sequestration by trees could provide relatively low cost net emission reductions[1,2,3,4]. Most of the carbon enters the ecosystem through the process of photosynthesis in the leaves. After the litter fall, the detritus is decomposed and forms soil organic carbon by microbial process. Intergovernmental Panel on Climate Change has recognized soil organic carbon pool as one of the five major carbon pools for the Land Use Land Use Change in Forestry sector. It is mandatory for all nations to provide soil organic carbon pool and changes from LULUCF sector under National Communications to the United Nation's Framework Convention on Climate Change.

Soil especially, the forest soil is one of the main sinks of

* Corresponding author:

sharmasd@icfre.org (Satinder Dev Sharma)

Published online at http://journal.sapub.org/ijaf

Copyright (C) 2011 Scientific \& Academic Publishing. All Rights Reserved carbon on earth because these soils normally contain higher soil organic matter however, the soil organic carbon (SOC) has been ignored since long because it was treated as a dead biomass. Soil contains an important pool of active carbon that plays a major role in the global carbon cycle[5,6]. Soil organic matter is a key component of terrestrial ecosystem. Enhanced sequestration of atmospheric $\mathrm{CO}_{2}$ in the soil, ultimately as stable soil organic matter, provides a more lasting solution than sequestering $\mathrm{CO}_{2}$ in standing biomass. Soils store 2.5 to 3.0 times as much that stored in plants[7] and two to three times more than the atmospheric as $\mathrm{CO}_{2}[8]$ The conversion of natural vegetation to various land uses results in rapid decline in soil organic matter[9]. Up to $87 \%$ decrease in soil organic carbon due to deforestation has been reported by researchers[10,11]. Land use and soil management practices can significantly influence soil organic carbon dynamics and carbon flux from the soil[9,12].

No systematic project / study has been undertaken to estimate the soil organic carbon pool in forests, as well as in other land uses in the Garhwal Himalayan zone. Although some investigations have been carried out and data generated on the soil organic carbon pool in the forests, but it was on the basis of desk review by using some indirect methods or using some assumptions. Soil organic carbon in India based 
on different forest types were estimated[13] but the bulk density, which is the key factor for soil organic carbon estimation has been calculated indirectly in their method.

Therefore, a study was conducted to estimate SOC pool under different land uses. The results of this study have provided the authentic and comprehensive estimates of the SOC pool under different land uses and vegetation covers. Information generated from this study can be used as a benchmark for future work to estimate the changes in SOC pool in these land uses.

\section{Materials and Methods}

The study was carried out in part of Garhwal region of Himalayas which includes Dehra Dun Forest Division, Mussoorie Forest Division, Chakrata Forest Division, Kalsi Soil Conservation Forest Division and part of Rajaji National Park. It lies between $29^{\circ} 56^{\prime} 36^{\prime \prime} \mathrm{N}$ to $30^{\circ} 58^{\prime} 26^{\prime \prime} \mathrm{N}$ latitude and $77^{\circ} 34^{\prime} 36^{\prime \prime} \mathrm{E}$ to $78^{\circ} 18^{\prime} 22^{\prime \prime} \mathrm{E}$ longitude. The sites for soil sampling were selected in four land uses viz. Forests, Plantations, Horticulture and Grasslands. Under forests land use, the SOC pool was estimated in S. robusta, C. deodara, Q. leucotrichophora, P. roxburghii, P. smithiana \& A. pindrow, $P$. wallichiana and Miscellaneous forests. Under horticulture land use the SOC was estimated in P.malus, P. guava, M. indica, Citrus spp. and L. chinen- sis orchards and under plantation land use the SOC was estimated in block plantations of Eucalyptus spp., T. grandis, D. sissoo and P. roxburghii. Area under different land uses were visited and systematic random sampling was applied for selection of sites in each land use and geographical coordinates and altitude of the sampling sites were recorded by GPS. Five samples were randomly collected for organic carbon estimation and two samples were collected for bulk density and coarse fragment estimation from each sampling sites. In all 154 sampling sites were selected and 1078 soil samples were collected for SOC pool estimation, including 607 soil samples from the forests, 175 samples from the horticulture, 268 samples from the plantations and 28 samples from grasslands. Variation in the number of samples was due to difference in area available under particular land use / species. Information on the sites selected and the number of samples collected are presented in Table 1.

Because the input of organic matter is largely from aboveground litter, forest soil organic matter tends to concentrate in the upper soil horizons, with roughly half of the soil organic carbon of the top $100 \mathrm{~cm}$ of mineral soil being held in the upper $30 \mathrm{~cm}$ layer. The carbon held in the upper profile is often the most chemically decomposable, and the most directly exposed to natural and anthropogenic disturbances[14]. Therefore, soil organic carbon pool was estimated up to the depth of $30 \mathrm{~cm}$ in this study.

Table 1. Details of the sampling sites in garhwal himalayas

\begin{tabular}{|c|c|c|c|c|}
\hline $\begin{array}{l}\text { Sl. } \\
\text { No. }\end{array}$ & Vegetation Cover & $\begin{array}{l}\text { Altitude } \\
(\mathrm{m})\end{array}$ & Area Covered & $\begin{array}{l}\text { No. of samples } \\
\text { Collected }\end{array}$ \\
\hline \multicolumn{3}{|c|}{ Forest Land Use } & Forest Range & \\
\hline 1 & S.robusta & $363-950$ & $\begin{array}{l}\text { Rajpur, Raipur, Chuhurpur, Langha, Jhajra, Asarori, Lachhiwala, } \\
\text { Barkot, Timli, Thano, Kalsi, Ramgarh, Rshikesh, Motichur and } \\
\text { Kansro }\end{array}$ & 252 \\
\hline 2 & C. deodara & $1622-2618$ & Kanaser, Mussoorie, Cantonment board and River & 56 \\
\hline 3 & Q. leucotrichophora & $1513-2440$ & Mussoorie, Kampty, Kanaser and Cantonment board & 110 \\
\hline 4 & P. roxburghii & $963-1846$ & River & 14 \\
\hline 5 & P. smithiana \& A. pindrow & $2314-2637$ & Kanaser & 28 \\
\hline 6 & Miscellaneous & $306-1539$ & $\begin{array}{c}\text { Asarori, Lachhiwal, Barkot, Thano, Kalsi, Timli, Motichur, } \\
\text { Rshikesh, Gauri and Mussoorie }\end{array}$ & 133 \\
\hline 7 & P. wallichiana & $2235-2383$ & Kanaser and Cantonment board & 14 \\
\hline \multicolumn{3}{|c|}{ Plantation Land Use } & Location & \\
\hline 1 & Eucalyptus spp. & $418-845$ & $\begin{array}{l}\text { Vikas Nagar, Kalsi, Aambagh, Herbartpur, Katapatter, } \\
\text { Baniawala, Gajrara, Timli, Rangarh and Sahspur }\end{array}$ & 98 \\
\hline 2 & D. sissoo & $381-647$ & $\begin{array}{c}\text { Badawala, Suddowala, Charba, Vikas Nagar, Raipur, Kalsi, } \\
\text { Herbartpur, Lachhiwal and Doiwala }\end{array}$ & 58 \\
\hline 3 & T. grandis & $401-749$ & $\begin{array}{c}\text { Badawala, Vikas Nagar, Raipur, Sahspur, Laltappad, Rudrapur, } \\
\text { Thano, Doiwala, Motichur, Kalsi and Aambagh }\end{array}$ & 91 \\
\hline 4 & P. roxburghii & $515-1729$ & Suridhar, Badawala and Kalsi & 21 \\
\hline \multicolumn{3}{|c|}{ Horticulture land use } & Location & \\
\hline 1 & M. indica & $396-670$ & $\begin{array}{l}\text { Jassuwala, Manduwala, Vikasnagar, Badawala, Rajewala, Lax- } \\
\text { mipur, Kalsi, Herbertpur, Dhakrani and Sahaspur }\end{array}$ & 70 \\
\hline 2 & L. chinensis & $451-677$ & $\begin{array}{l}\text { Jassuwala, Herbertpur, Rusulpur, Miyawala, Ranipokhari and } \\
\text { Kalsi }\end{array}$ & 42 \\
\hline 3 & P. guava & $455-690$ & Selakui, Kunja, Siriothano and Sashpur & 21 \\
\hline 4 & P. malus & $1988-2353$ & Koti, Asmad and Jhadi (Chakrata) & 35 \\
\hline 5. & Citrus spp. & 691 & Sirio thano & 7 \\
\hline \multicolumn{3}{|c|}{ Grassland land Use } & Location & \\
\hline \multirow[t]{2}{*}{1} & Grassland & $2389-2551$ & Deoban and Loharu & 28 \\
\hline & & & Total Samples Collected & 1078 \\
\hline
\end{tabular}


Soil samples were collected by digging a pit of $30 \mathrm{~cm}^{3}$. Samples were processed in laboratory and the soil organic carbon was estimated by standard Walkley and Black method[15] method. Amount of coarse fragments were estimated in each sample collected from different sites and deducted from the soil weight to get an accurate soil weight on hectare basis. Bulk density at every site was estimated by standard core method[16]. All the methods used in this study are in accordance to Carbon Inventory Methods[17].

The data for SOC pool was calculated by using the following equation as suggested by IPCC Good Practice Guidance for LULUCF[14]:

\section{Equation for SOC :}

$\mathrm{SOC}=\sum_{\text {Horizon }=1}^{\text {Horizon=n }} \mathrm{SOC}_{\text {horizon }}=\sum_{\text {Horizon=1 }}^{\text {Horizon=n }}([\mathrm{SOC}] *$ Bulk density $*$ depth $*(1-\mathrm{C}$ fragments $) * 10)_{\text {horizon }}$

Where,

SOC $=$ Representative soil organic carbon content for the forest type and soil of interest, tones $\mathrm{C}$ ha. ${ }^{-1}$

$\mathrm{SOC}_{\text {horizon }}=$ Soil organic carbon content for a constituent soil horizon, tones $\mathrm{C} \mathrm{ha}^{-1}$

$[\mathrm{SOC}]=$ Concentration of SOC in a given soil mass obtained from analysis, $\mathrm{g} \mathrm{C}(\mathrm{kg} \mathrm{soil})^{-1}$

Bulk density $=$ Soil mass per sample volume, tones soil $\mathrm{m}^{-3}$ (equivalent to $\mathrm{Mg} \mathrm{m}^{-3}$ )

Depth $=$ Horizon depth or thickness of soil layer, $m$

C Fragment $=\%$ volume of coarse fragments $/ 100$, dimensionless

\section{Results and Discussion}

Table 2. Soil organic carbon pool under different land uses in garhwal Himalayas (up to $30 \mathrm{~cm}$ )

\begin{tabular}{|c|c|c|c|c|c|c|}
\hline $\begin{array}{l}\text { Sl. } \\
\text { No. }\end{array}$ & Forest Cover & $\begin{array}{c}\text { SOC Pool } \\
\left(\mathrm{t} \mathrm{ha}^{-1}\right) \\
\end{array}$ & SD & $\begin{array}{l}\text { Mitigation Potential } \\
\text { (Land use wise) } \\
\end{array}$ & $\begin{array}{c}\text { Mitigation Potential } \\
\text { (Combined for all land uses) } \\
\end{array}$ & S E \\
\hline & \multicolumn{6}{|c|}{ Forest Land Use } \\
\hline 1 & P. smithiana \& A .pindrow & $132.00^{\mathrm{a}}$ & \pm 22.7635 & 2.22 & 3.39 & 5.09 \\
\hline 2 & C. deodara & $120.35^{\mathrm{a}}$ & \pm 25.8666 & 2.02 & 3.09 & 4.09 \\
\hline 3 & Q. leucotrichophora & $102.96^{\mathrm{b}}$ & \pm 33.3769 & 1.73 & 2.65 & 3.69 \\
\hline 4 & P. wallichiana & $85.67^{\mathrm{c}}$ & \pm 30.2055 & 1.44 & 2.20 & 9.55 \\
\hline 5 & Miscellaneous & $64.31^{\mathrm{d}}$ & \pm 32.5510 & 1.08 & 1.66 & 3.34 \\
\hline 6 & P. roxburghii & $62.80^{\mathrm{d}}$ & \pm 26.4274 & 1.05 & 1.61 & 8.36 \\
\hline \multirow[t]{3}{*}{7} & S. robusta & $60.07^{\mathrm{d}}$ & \pm 28.0907 & 1.00 & 1.53 & 2.09 \\
\hline & Average & 78.49 & \pm 38.3464 & -- & -- & 1.83 \\
\hline & \multicolumn{6}{|c|}{ Plantation Land use } \\
\hline 1 & Eucalyptus spp. & $54.03^{\mathrm{a}}$ & \pm 29.9977 & 1.32 & 1.39 & 3.59 \\
\hline 2 & P. roxburghii & $46.07^{\mathrm{a}}$ & \pm 18.5280 & 1.13 & 1.18 & 4.78 \\
\hline 3 & Teak & $41.19^{\mathrm{a}}$ & \pm 25.0694 & 1.01 & 1.05 & 3.10 \\
\hline \multirow[t]{3}{*}{4} & D. sissoo & $40.80^{\mathrm{a}}$ & \pm 25.9569 & 1.00 & 1.05 & 3.96 \\
\hline & Average & 46.13 & \pm 27.2518 & -- & -- & 1.96 \\
\hline & \multicolumn{6}{|c|}{ Horticulture Land use } \\
\hline 1 & P. malus & $105.20^{\mathrm{a}}$ & \pm 30.4064 & 2.71 & 2.71 & 7.85 \\
\hline 2 & M. indica & $53.24^{\mathrm{b}}$ & \pm 28.2642 & 1.37 & 1.37 & 4.00 \\
\hline 3 & L. chinensis & $45.47^{\mathrm{b}}$ & \pm 17.5555 & 1.17 & 1.17 & 3.21 \\
\hline 4 & Citrus spp. & $43.10^{\mathrm{b}}$ & \pm 3.4918 & 1.11 & 1.11 & 1.56 \\
\hline \multirow[t]{3}{*}{5} & P. guava & $38.88^{\mathrm{b}}$ & \pm 20.1335 & 1.00 & 1.00 & 4.03 \\
\hline & Average & 54.33 & \pm 30.9297 & -- & -- & 2.76 \\
\hline & \multicolumn{6}{|c|}{ Grassland Land Use } \\
\hline 1 & Grasslands & 75.76 & \pm 44.0082 & -- & 1.95 & 9.84 \\
\hline
\end{tabular}

Same alphabets represent statistically at par group

\section{SOC pool under $P$. smithiana \& $A$.pindrow was maxi-} mum $\left(132.00 \mathrm{tha}^{-1}\right)$ followed by C. deodara $\left(120.35 \mathrm{t} \mathrm{ha}^{-1}\right)$, Q. leucotrichophora $\left(102.96 \mathrm{t} \mathrm{ha}^{-1}\right)$ and the least was in $S$. robusta $\left(60.07 \mathrm{t} \mathrm{ha}^{-1}\right)$ (Table 2$)$. SOC pool was nearly similar under $S$. robusta, P. roxburghii and Miscellaneous forests. It was $9.68 \%$ higher under $P$. smithiana \& $A$. pindrow as compared to $C$. deodara, $28.21 \%$ higher as compared to $Q$. leucotrichophora and $119.74 \%$ higher as compared to $S$. robusta forests. SOC pool under C. deodara was $16.89 \%$ higher as compared to Q. leucotrichophora and $40.48 \%$ higher as compared to $P$. wallichiana while $87.14 \%$, $91.64 \% 100.35 \%$ higher in comparison to Miscellaneous, $P$. roxburghii and $S$. robusta forests respectively. Under $Q$. leucotrichophora forests, SOC pool was $20.18 \%$ higher as compared to $P$. wallichiana and $60.10 \%, 63.95 \%$ and $71.40 \%$ higher as compared to Miscellaneous, $P$. roxburghii and S. robusta respectively. SOC pool under Miscellaneous forests was marginally higher as compared to $P$. roxburghii $(2.40 \%)$ and $S$. robusta $(7.06 \%)$. Subset for $\alpha=0.05$ indicate that $P$. smithiana \& A. pindrow and $C$. deodara stand separately (a), Q. leucotrichophora stand separately (b), $P$. wallichiana stand separately (c) and S. robusta, P. roxburghii and Miscellaneous are together (d) (Table 2). Standard Error varied from 2.09 in $S$. robusta forests to 9.55 in $P$. wallichiana forests. Reason of slightly higher standard error in $P$. wallichiana may be due to the fact that area under $P$. wallichiana forests was very less in study area therefore, lesser numbers of the samples were collected, hence this variation was expected. 
Mitigation potential was worked out against the SOC pool in S. robusta which was the minimum. It was observed that $P$. smithiana \& A. pindrow forests (2.22) and C. deodara forests (2.02) have higher mitigation potential. It indicated that soils under these forests can have more than double SOC pool as compared to S. robusta. Q. leucotrichophora forests have moderately higher (1.73) while $P$.roxburghii (1.05) and Miscellaneous (1.08) have similar mitigation potential.

Fraction of total SOC pool shared by each forest cover has been depicted in Figure 1. Maximum fraction (21.01\%) was occupied by $P$. smithiana \& A. pindrow forests followed by $C$. deodara (19.16\%), Q. leucotrichophora $(16.39 \%), \quad P . \quad$ wallichiana (13.68\%), Miscellaneous (10.24\%), P. roxburghii $(9.99 \%)$ and the S. robusta $(9.56 \%)$. On an average, the forests have $78.49 \mathrm{t} \mathrm{ha}^{-1}$ soil organic carbon pool. The recorded forest area owned by Forest Department in the study area was $1,52,270.761$ hectare[18] therefore, total SOC pool under these forests was $1,19,51,732.03$ tones (11.95 million tons). In addition to this, the study area had $34,201.60$ hectare forests owned by Revenue department which contained 26,84,483.58 tones (2.68 million tons) SOC pool. Further 7,658.60 hectare of forests were owned by Van Panchyats which contained $6,01,123.51$ tones (0.60 million tons) SOC store. Besides this, 7,699.10 hectare forests were owned by private or others in this area which had 6,04,302.35 tones $(0.60$ million tons) of SOC store. On summing up the SOC contained in all categories of forests it was found that the forests of the study area have $1,58,41,641.84$ tones (15.84 million tons) SOC store.

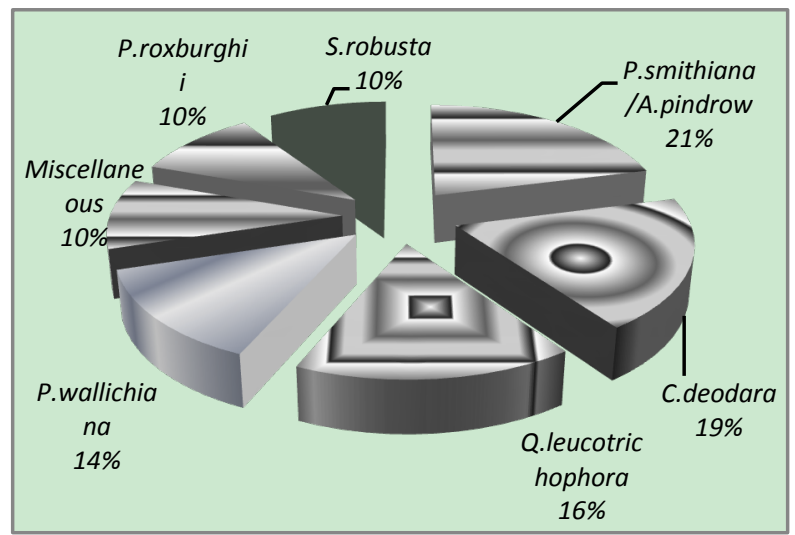

Figure 1. SOC percent share of different forest covers under Forest Land Use.

\subsection{Soil Organic Pool under Tree Plantations}

The average SOC pool in tree plantation was 46.13 tha $^{-1}$. SOC pool under Eucalyptus spp. was maximum $\left(54.03 \mathrm{tha}^{-1}\right)$ followed by $P$. roxburghii $\left(46.07 \mathrm{t} \mathrm{ha}^{-1}\right), T$. grandis $(41.19 \mathrm{t}$ $\left.\mathrm{ha}^{-1}\right)$ and the least was under D. sissoo $\left(40.8 \mathrm{t} \mathrm{ha}^{-1}\right)$. It has been reported that tree height of $7 \mathrm{~m}$ and above had more influence on soil properties than smaller trees[19]. SOC pool under Eucalyptus spp. was $17.28 \%$ higher as compared to $P$. roxburghii while it was $31.17 \%$ and $32.43 \%$ higher in comparison to $T$. grandis and $D$. sissoo respectively.
Fraction of total SOC pool shared by each plantation has been shown in Figure 2. SOC pool under Eucalyptus spp. has contributed maximum (29.67\%), followed by $P$. roxburghii $(25.30 \%)$, T. grandis $(22.62 \%)$ and the minimum was occupied by $D$. sissoo (22.40\%). Standard error varied from 3.10 to 4.78 which reflects low variation in data. Mitigation potential was worked out for these plantations against $D$. sissoo as it had the minimum SOC pool. It was observed that Eucalyptus spp. has the maximum mitigation potential (1.32) while all other plantations do not differ much.

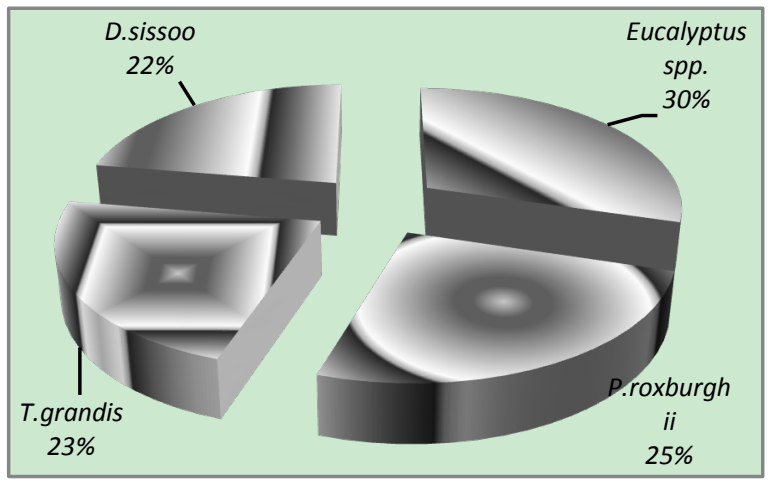

Figure 2. SOC percent share of different plantations.

\subsection{Soil Organic Pool under Horticulture and Grasslands}

SOC pool under different orchards was estimated and it was found maximum in P. malus $\left(105.2 \mathrm{t} \mathrm{ha}^{-1}\right)$ followed by M. indica $\left(53.24 \mathrm{t} \mathrm{ha}^{-1}\right)$, L. chinensis $\left(45.47 \mathrm{t} \mathrm{ha}^{-1}\right)$, Citrus spp. $\left(43.10 \mathrm{t} \mathrm{ha}^{-1}\right)$ and the P. guava $\left(38.88 \mathrm{t} \mathrm{ha}^{-1}\right)$. However the average SOC pool of this region under horticulture land use was $54.33 \mathrm{t} \mathrm{ha}^{-1}$. Higher SOC pool under P. malus orchards may be because of the reason that these orchards were well maintained and farmers provided lot of inputs including farm yard manure and therefore, higher SOC pool was expected. $M$. indica orchards had $17.08 \%, 23.52 \%$ and $36.93 \%$ higher SOC pool as compared to L. chinensis, $C i$ trus spp. and $P$. guava respectively. SOC pool under $L$. chinensis was $5.50 \%$ higher as compared to Citrus spp. while $16.95 \%$ higher in comparison to $P$. guava. Standard error varied from 1.56 in Citrus spp. to 4.03 in P. guava except 7.85 in P. malus orchards. Little higher standard error was expected as management of $P$. malus orchards is different in different farms depending upon the financial status of the farm owner.

Maximum share of total SOC pool was shared by P. malus $(36.80 \%)$ followed by $M$. indica $(18.62 \%)$, L. chinensis (15.90\%), Citrus spp. (15.08\%) and P. guava (13.60\%) (Figure. 3). P. malus has high mitigation potential (2.71) which indicates that it can store more than double SOC pool as compared to $P$. guava. Mitigation potential of $L$. chinensis, Citrus spp. and P. guava was not much different. The study area has 25336 hectare under horticulture and the soils under this land use have 1.40 million tons SOC pool which is $13.05 \%$ of the total SOC pool of the horticulture land use of Uttarakhand state. 


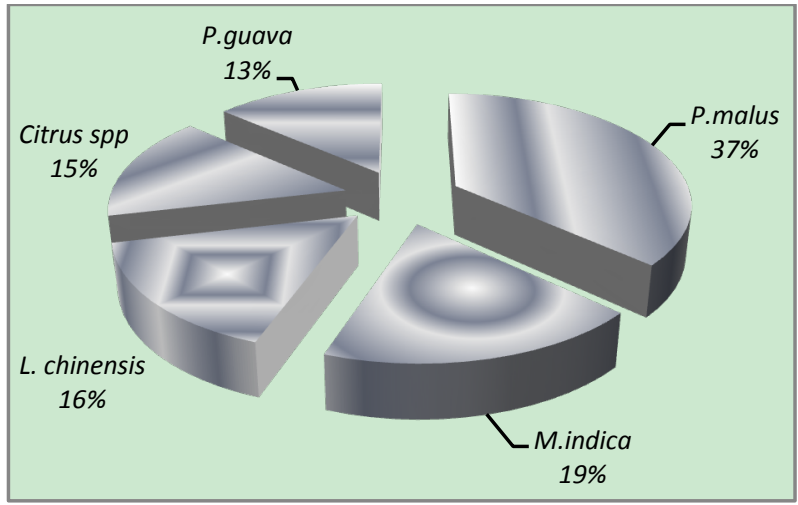

Figure 3. SOC percent share of different orchards under horticulture land use

SOC Pool was also estimated in the soils of grasslands and it was found that SOC pool was $75.76 \mathrm{t} \mathrm{ha}^{-1}$ and the standard error was 9.84 (Table 1). SOC pool under grassland was $66.42 \%$ higher as compared to Plantations and $32.50 \%$ higher in comparison to Horticulture land use.

\section{Statistical Analysis}

Results of one-way ANOVA indicated that SOC pools between the forestry species were significantly different at 0.05 level (Variance ratio, $\mathrm{F}=48.764 ; \mathrm{p}=<0.05$ ). SOC pool under $P$. smithiana \& A. pindrow was significantly different from the SOC pool under $Q$. leucotrichophora, $S$. robusta, $P$. roxburghii, $P$. wallichiana and Miscellaneous forests and SOC pool under $C$. deodara was also statistically significantly different from $Q$. leucotrichophora, $S$. robusta, $P$. roxburghii, $P$. wallichiana and Miscellaneous forests. SOC pool under $Q$. leucotrichophora was statistically significantly different from $S$. robusta, Miscellaneous and $P$. roxburghii while SOC pool under P. wallichiana forests was significantly different from $S$. robusta and Miscellaneous forests (Table 2).

When SOC pool of different plantations was tested statistically, it was found to be significantly different at $0.05 \mathrm{lev}-$ el (Variance ratio, $\mathrm{F}=3.337 ; \mathrm{p}<0.05$ ). SOC pool under Eucalyptus spp. was statistically different from $T$. grandis and $D$. sissoo and it differed non-significantly from $D$. sissoo, T. grandis and P. roxburghii. When SOC pool of different orchards was tested it was observed that the species i.e. M. indica, L. chinensis, P. malus, P.guava and Citrus $s p p$. were statistically different at 0.05 level (Variance ratio, $\mathrm{F}=20.263 ; \mathrm{p}<0.05$ ). SOC pool under $M$. indica was significantly different from $P$. malus and P.guava. SOC pool under $P$. malus was significantly different with all other orchards (Table 3).

Table 3. Statistically significant mean differences on the basis of CD (LSD)

\begin{tabular}{|c|c|c|c|}
\hline S1 No. & Vegetation & Mean Difference & P value \\
\hline \multicolumn{4}{|c|}{ Forest Land Use } \\
\hline 1 & P. smithiana \& A pindrow Vs Q. leucotrichophora & $29.0421 *$ & 0.000 \\
\hline 2 & P. smithiana \& A pindrow Vs $P$. wallichiana & $46.3320 *$ & 0.000 \\
\hline 3 & P. smithiana \& A pindrow Vs Miscellaneous & $67.6907 *$ & 0.000 \\
\hline 4 & P. smithiana \& A .pindrow Vs P. roxburghii & $69.2060 *$ & 0.000 \\
\hline 5 & P. smithiana \& A .pindrow Vs S.robusta & $71.9323 *$ & 0.000 \\
\hline 6 & C. deodara Vs S.robusta & $60.2750 *$ & 0.000 \\
\hline 7 & C. deodara Vs Q. leucotrichophora & $17.3849 *$ & 0.003 \\
\hline 8 & C. deodara Vs P. wallichiana & $34.6747 *$ & 0.001 \\
\hline 9 & C. deodara Vs Miscellaneous & $56.0334 *$ & 0.000 \\
\hline 10 & C. deodara Vs P. roxburghii & $57.5487 *$ & 0.000 \\
\hline 11 & Q. leucotrichophora Vs Miscellaneous & $38.6485 *$ & 0.000 \\
\hline 12 & Q. leucotrichophora Vs P.roxburghii & $40.1639 *$ & 0.000 \\
\hline 13 & Q. leucotrichophora Vs S. robusta & $42.8901 *$ & 0.000 \\
\hline 14 & P. wallichiana Vs Miscellaneous & $21.3587 *$ & 0.032 \\
\hline 15 & P. wallichiana Vs $S$. robusta & $25.6003 *$ & 0.008 \\
\hline \multicolumn{4}{|c|}{ Plantation Land Use } \\
\hline 1 & Eucalyptus spp. Vs T. grandis & $12.8399 *$ & 0.006 \\
\hline 2 & Eucalyptus spp. Vs D. sissoo & $13.2236^{*}$ & 0.012 \\
\hline \multicolumn{4}{|c|}{ Horticulture Land Use } \\
\hline 1 & P. malus Vs $M$. indica & $51.9528 *$ & 0.000 \\
\hline 2 & P. malus Vs L. chinensis & $59.7250 *$ & 0.000 \\
\hline 3 & P. malus Vs P.guava & $66.3160 *$ & 0.000 \\
\hline 4 & P. malus Vs Citrus spp. & $62.1000^{*}$ & 0.000 \\
\hline 5 & M. indica Vs P. guava & $14.3632 *$ & 0.017 \\
\hline \multicolumn{4}{|c|}{ Overall } \\
\hline 1 & Forests Vs Horticulture & $24.1646^{*}$ & 0.000 \\
\hline 2 & Forests Vs Plantations & $32.3604 *$ & 0.000 \\
\hline 3 & Horticulture Vs Plantation & $8.1957 *$ & 0.041 \\
\hline 4 & Grassland Vs Horticulture & $21.4213 *$ & 0.011 \\
\hline 5 & Grassland Vs Plantations & $29.6171 *$ & 0.000 \\
\hline
\end{tabular}


When the overall means of SOC pool under forests, plantations, grasslands and orchards were compared through ANOVA, SOC pool between above groups were statistically significantly different at 0.05 level (Variance ratio, $\mathrm{F}=44.646 ; \mathrm{p}<0.05)$. It was observed that differences in SOC pool under forests were significantly different from plantations and horticulture while under grassland and forest it did not differ significantly. Subsets for $\alpha=0.05$ indicated that SOC pool under Horticulture and plantations were homogenous and, hence, placed in one group while Forests and grassland, significantly different, were placed in the other group. It was estimated that SOC pool under forests was $97.13 \%$ higher as compared to plantations and $56.94 \%$ higher in comparison to horticulture while $18.45 \%$ higher as compared to grassland.

All the vegetations, irrespective of the land uses, were integrated and the mitigation potential was worked out against $P$. guava which had the lowest SOC pool. It was observed that maximum mitigation potential was 3.39 for $P$. smithiana \& A. pindrow followed by 3.09 for $C$. deodara. It indicated that soils under $P$. smithiana \& A. pindrow and $C$. deodara can hold more than three time SOC pool as compared to $P$. guava while soils under $Q$. leucotrichophora, $P$. wallichiana, $P$. malus and grasslands can hold more than double. The plantations of $P$. roxburghii, $T$. grandis and $D$. sissoo and the orchards of $L$. chinensis and Citrus spp. had nearly similar mitigation potential.

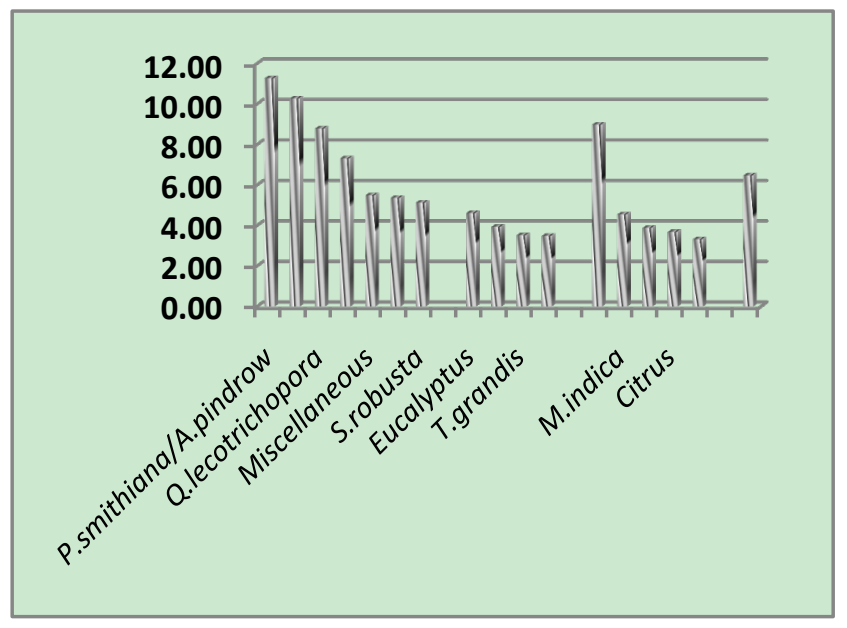

Figure 4. SOC percent share of different vegetations.

Share of total SOC pool was worked out after integrating all the vegetation cover (Figure. 4). Soils under $P$. smithiana $\&$ A. pindrow contributed maximum share $(11.26 \%)$ followed by $C$. deodara (10.27\%). Soils under P. malus orchards $(8.98 \%)$ and $Q$. leucotrichophora $(8.79 \%)$ had nearly similar proportion. Soils under Miscellaneous forest, $P$. roxburghii, and $S$.robusta also had nearly similar share. Soils under $T$. grandis, $D$. sissoo and $P$. roxburghii plantation and L. chinensis, Citrus spp. and P. guava orchards shared almost same fraction out of the total SOC pool. It is evident from the data that maximum share was contributed by forest vegetations and thus the deforestation affects the SOC pool adversely. Most of the forests in tropics are being cleared for agriculture and other land uses, which is causing the formation of less productive soils and these are even more susceptible to degradation[20].

SOC pool under forests was the maximum followed by grasslands, horticulture and the least was in the soils of plantations. Forests have grater canopies and provide the litter in larger quantity therefore, accumulation of carbon is higher. About $40 \%$ of the total SOC stock of the global soils resides in forest ecosystem[21]. The Himalayan zones, with dense forest vegetation, cover nearly $19 \%$ of India and contain 33\% of SOC reserves of the country[22]. Land use and soil management practices can significantly influence soil organic carbon dynamics and carbon flux of the soil[12,23]. Gua and Gifford[24] reported that soil carbon stocks decline after land use change from native forest to plantation (-13\%) or native forest to crop land (-42\%). Some researchers have also reported that soil organic matter may change depending on numerous factors, including climate, vegetation type, nutrient availability, disturbance, and land use and management practice[25,26]. Soil organic carbon is sensitive to impact of anthropogenic activities. The conversion of natural vegetation to various land uses results in rapid decline in soil organic matter[9]. Conversion of marginal arable land to forestry or grassland can rapidly increase soil carbon sequestration. For example, analysis of long term crop experiments indicated that increasing crop rotation complexity increased SOC sequestration by $20 \mathrm{~g} \mathrm{C} \mathrm{m}^{-2} \mathrm{yr}^{-1}$, on average[27].

\section{Conclusions}

SOC pool was the maximum in the forest lands followed by grass lands, orchards and plantation areas. Differences in SOC pool under different land uses were statistically significant $(\mathrm{p}<0.05)$. The average content of SOC was $78.49 \mathrm{t}$ $\mathrm{ha}^{-1}$ in forests, $54.33 \mathrm{t} \mathrm{ha}^{-1}$ in orchards, $46.13 \mathrm{t} \mathrm{ha}^{-1}$ in plantations and $75.76 \mathrm{t} \mathrm{ha}^{-1}$ in grasslands. P. smithiana \& $A$. pindrow forests had higher potential to store SOC among the forest species whereas the SOC storage potential of $P$. malus was higher in case of fruit crops. The capacity to store SOC, in case of Eucalyptus spp. was 1.3 times higher than $D$. sissoo in case of tree plantations.

\section{REFERENCES}

[1] Parks, P. J. and. Hardie, I. W., 1995, Least-cost forest carbon reserves: Cost effective subsidies to convert marginal agricultural land to forests. Land Economics , 71(1), 122:136

[2] Plantinga, A. J. and Birdsey, R. A., 1995, Carbon fluxes resulting from U.S. Private Timberland Management. Climate Change, 23, 37-53

[3] Callaway, J. M. and B. Mc Card., 1996, The economic consequences of substituting carbon payments for crop subsidies in US agriculture. Environmental and Resource Economics 
1996, 7 (1), 15-43

[4] Stavin, R. N., 1999, The costs of carbon sequestration: A reveled - Preference approach. American Economic Review, 89 (4), 994-1009

[5] Melilo, J. M., Kicklighter, D., McGuire, A., Peterjohn, W. and. Newkirk. K, 1995, Global change and its effects on soil organic carbon stocks. In: Dahlem Conference Proceedings, John Wiley and Sons, New York., 175-189

[6] Prentice, I. C., Farquhar, G. D., Fasham, M. J. R., Goulden, M. L. and Heimann, M.., 2003, The carbon cycle and atmospheric $\mathrm{CO}_{2}$. In: The Third Assessment Report of Intergovernmental Panel on Climate Change (IPCC). Chapter 3, Cambridge University Press, Cambridge

[7] Post, W. M., Pengh, T. H., Emanuel, W., King, A. W., Dale, V. H. and Delnglis., 1990, The global carbon cycle. American Science, 78, 310-326

[8] Davidson, E. A., Trumbore, S. E and Amudson R., 2000, Soil warming and organic carbon content. Nature, 408, 789-790

[9] Post, W. M. and Kwon, K. C., 2000, Soil carbon sequestration and land use change Process and potential. Global Change Biology, 6, 317 - 327

[10] Totey, N. G. Bhowmik, A. K. and Khatri, K.,1986, Performance of Shorea robusta on the soils derived from different parent material in Shahdol forest division, M. P. Indian Forester, $112(1), 18-31$

[11] Singh, J.; Borah, I. P. and Baruah, A., 1995, Soil characteristics under three different plant communities of northeast India. Indian Forester, 121 (12), 1130 - 1134

[12] Tian, H., Melillo, J. M. and Kicklighter, D. W., 2002, Regional carbon dynamics in monsoon Asia and implications for the global carbon cycle. Global and Planetary Change, 37, 201-217

[13] Chhabra, A., Palria, S.and Dadhwal, V. K., 2002, Growing stock based forest biomass in Indian forests. Biomass and bio-energy, 22 (3), 187-194

[14] IPCC. 2003, Good Practice Guidance for Land Use, Land Use Change and Forestry. Published by the Institute for Global Environmental Strategies (IGES) for the IPCC. Publishers Institute for Global Environmental Strategies, Japan
[15] Walkley, A. and Black, I. A., 1934, An Examination of Degtjareff Method for Determining Soil Organic Matter and a Proposed Modification of the Chromic Acid Titration Method. Soil Science, 37, 29-37

[16] Wilde, S. A., Voigt, G. K. and Iyer, J. G., 1994, Soil and Plant Analysis for Tree Culture. Oxford Publishing House, Calcutta, India

[17] Ravindranath, N. H. and Ostwald, M., 2008, Carbon Inventory Methods: Handbook for Greenhouse Gas Inventory, Carbon Mitigation and Round wood Production Projects. Springer Publications

[18] Anon., 2010, Uttaranchal Forest Statistics 2009 - 2010, Forest Department, Uttarakhand

[19] Isichei, A. O. and Moughalu, J. I., 1992, The effects of tree canopy cover on soil fertility in a Nigerian savanna. Journal of Tropical Ecology, 8 (3), 329-338

[20] Brown, S., 1993, Estimating biomass and biomass change of tropical forests: A primer. FAO Forestry, Paper 134, FAO, Rome

[21] Eswaran H, Reich P. F., Kimble J. M., Beinroth F. H., Padmanabhan E., Moncharoen P., 1999, Global Climate Change and Pedogenic Carbonates (Ed.) by: Lal R, et al. Lewis Publishers, Fl, USA, 15-25

[22] Bhattacharyya, T., Pal, D. K., Chandran, P., Ray, S. K., Mandal, C., and Talpande, B., 2008, Soil carbon storage capacity as a tool to prioritize area for carbon sequestration, Current Science, 95 (4), $482-484$

[23] Batjes, N. H.,1996, Total carbon and nitrogen in the soils of the world. European Journal of Soil Scence, 47, 151-163

[24] Gua, L. B. and Gifford, R. M., 2002, Soil Carbon stocks and land use change: a meta analysis. Global Change Biology, 8 (4), $345-360$

[25] Six, J. and Jastrow, J. D., 2002, Organic matter turnover. Encyclopedia Soil Science, 936-942

[26] Baker, D. F., 2007, Reassessing carbon sinks, Science, 316, 1708-1709

[27] West T. O., Post W. M., 2002, Soil organic carbon sequestration rates by tillage and crop rotation: A global data analysis. Soil Science Society of America Journal, 66, 1930-1946 